\title{
Annelid Borings on Brachiopod Shells From the Upper Ordovician of Peru. A Long-Distance Co-migration of Biotic Partners
}

\author{
Enrique Villas ${ }^{1}$, Eduardo Mayoral ${ }^{2,3}$, Ana Santos ${ }^{4 *}$, Jorge Colmenar ${ }^{5}$ and \\ Juan Carlos Gutiérrez-Marco ${ }^{6}$ \\ ' Departamento de Ciencias de la Tierra, Facultad de Ciencias, Universidad de Zaragoza, Zaragoza, Spain, \\ ${ }^{2}$ Departamento de Ciencias de la Tierra, Facultad de Ciencias Experimentales, Universidad de Huelva, Huelva, Spain, \\ ${ }^{3} \mathrm{CCTH}$ - Centro de Investigación Científico Tecnológico, Universidad de Huelva, Huelva, Spain, ${ }^{4}$ Facultad de Geología, \\ Universidad de Oviedo, Oviedo, Spain, ${ }^{5}$ Instituto Geológico y Minero de España, Madrid, Spain, ${ }^{6}$ Facultad Ciencias \\ Geológicas, Instituto de Geociencias (CSIC, UCM) and Área de Paleontología GEODESPAL, Madrid, Spain
}

OPEN ACCESS

Edited by:

Olev Vinn,

University of Tartu, Estonia

Reviewed by:

Michal Zaton

University of Silesia in Katowice,

Poland

Radek Mikuláš,

Academy of Sciences of the Czech

Republic (ASCR), Czechia

*Correspondence:

Ana Santos

aalexa.santos2021@gmail.com

Specialty section:

This article was submitted to Biogeography and Macroecology,

a section of the journal

Frontiers in Ecology and Evolution

Received: 28 August 2021

Accepted: 18 October 2021

Published: 05 November 2021

Citation:

Villas E, Mayoral E, Santos A, Colmenar J and Gutiérrez-Marco JC (2021) Annelid Borings on Brachiopod

Shells From the Upper Ordovician of Peru. A Long-Distance

Co-migration of Biotic Partners.

Front. Ecol. Evol. 9:766290.

doi: 10.3389/fevo.2021.766290
The Recent planktonic larvae of the polychaete spionids are some of the most widespread and abundant group of coastal meroplankton worldwide. To study the possible co-migration of biotic partners and determine whether they were host-specific, the type of biotic relationship between hosts and borers of an Upper Ordovician Peruvian brachiopod collection from the Proto-Andean margin of Gondwana was re-exanimated and compared with material from Wales (Avalonia). The species list studied is composed of Colaptomena expansa (41\%), Heterorthis retrorsistria (24\%), Horderleyella chacaltanai (19\%), Drabovinella minuscula (13\%), and Dinorthis cf. flabellulum (3\%) and coincides closely with that of the Dinorthis community described in the Caradoc series of North Wales. The borings attributed to these spionids have been identified as Palaeosabella prisca only present in the valves of Colaptomena expansa and Heterorthis retrorsistria. All the studied valves are disarticulated, with very low fragmentation and are randomly oriented in a context below the fair-weather wave base. The settling larvae would feed on their brachiopod host soft parts at an early stage, being the biotic interaction initially of the parasitic type. Since Palaeosabella borings from Peru and Wales are identical, as well as the species specificity of their producers with their brachiopod hosts, it can be concluded that the same spionid annelid species produced them. The Southern Westerlies current that connected the Proto-Andean margin of Gondwana with Avalonia must have been responsible for transporting the larvae of annelids and brachiopods in what had to be a successful biotic relationship over a great transoceanic distance.

Keywords: bioerosion, Palaeosabella, coevolution, commensalism, parasitism, palaeobiogeography

\section{INTRODUCTION}

The Recent spionid polychaetes are receiving great attention in present oceanographic research due to their boring activities on bivalve and gastropod shells of commercial interest for shellfisheries (Díaz-Díaz and Liñero-Arana, 2009; Skeel, 2009; Diez et al., 2011). Although the spionid species are generally geographically restricted, due to the limited dispersal potential of 
their larvae, the ballast water from ships and the introduction of infested exotic molluscs have expanded some of them to regions where they were previously unknown (Radashevsky and Olivares, 2005). The group is known to exist since the early Palaeozoic due to the characteristic borings they performed mainly on brachiopod shells (Cameron, 1969a,b; Taylor and Wilson, 2003; Bromley, 2004; Wilson, 2007), and great attention to the type of biotic relationship between the brachiopods and the annelids have been paid (Furlong and McRoberts, 2014). One of the oldest interactions between both groups has been recorded from the Upper Ordovician of Wales (Pickerill, 1976).

The brachiopods Colaptomena expansa (Sowerby, 1839) and Heterorthis retrorsistria (McCoy, 1851), from the Upper Ordovician of Wales, were described as the specific hosts of a spionid polychaete that produced the boring fossil Vermiforichnus in their shells (Pickerill, 1976). This paper revises the systematic assignment of Vermiforichnus to Palaeosabella, which along with Trypanites, are two of the characteristic ichnogenera of the Ordovician Bioerosion Revolution (OBR; Wilson and Palmer, 2001, 2006). This event marked the beginning of Phanerozoic diversity for macroborings, which involved a critical ecological change being the first borings that provide secondary niche space for cryptic organisms (Tapanila and Copper, 2002), among others for the annelids. This behaviour was probably favoured by increased predation pressure (Huntley and Kowalewski, 2007) that also led, at the same time, to increased infaunalisation of larger invertebrates, which began to diversify significantly after the Great Ordovician Biodiversification Event (Servais et al., 2010).

A revision of the brachiopod fossil collections made by Villas et al. (2015) in Peru has shown that an important part of the shells also displays borings similar to those from Wales. This fact is especially interesting since several Peruvian brachiopods coincide at the species level with the Welsh brachiopods. The coincidence is somewhat unusual considering the increasing differentiation of the brachiopod communities from the Mediterranean margin of Gondwana (Peru) and Avalonia (Wales) along the Ordovician (Harper et al., 2013; Torsvik and Cocks, 2017). By this time, the distance between Gondwana and Avalonia is depicted to be more than $3,000 \mathrm{~km}$ (Harper et al., 2013), justifying the great taxonomic differences at genus level between their brachiopod assemblages. Curiously, the brachiopod species cooccurring in Gondwana and Avalonia are proposed to be the specific hosts of Vermiforichnus: Colaptomena expansa and Heterorthis retrorsistria.

In this paper, we are revising the Peruvian brachiopod collections studied by Villas et al. (2015) to analyse the shell spionids borings and compare them with those from Wales. Also, we determine if the studied bioerosion is host specific and the type of biotic relationship between spionids borers and the brachiopods hosts. Finally, we discuss a possible co-migration of the studied brachiopods species and spionids borers in a transoceanic journey to come across the Rheic Ocean between both Gondwana and Avalonia.

\section{GEOGRAPHICAL AND GEOLOGICAL SETTING}

The studied ichnofossils occur about $50 \mathrm{~km}$ northwest of Lake Titicaca in the morphotectonic region of the Altiplano (high plains) of the Puno Department, southwestern Peru, belonging to the northern part of the Central Andean Palaeozoic Basin. They have been collected at the same fossiliferous locality of Calapuja from where Villas et al. (2015; Figure 1) studied several brachiopod assemblages, Vinn and Gutiérrez-Marco (2016; Figure 1) described new cornulitids and Ebbestad and GutiérrezMarco (2000; Figure 1) a new bellerophontoid gastropod. The precise location of the fossiliferous site at the Ticara Creek, west of the village of Calapuja and close to the main town of Juliaca, was described and figured in those papers.

A sandstone horizon has yielded the studied collection in the lower third of the Calapuja Formation. This stratigraphic unit crops out extensively along the valley of the Pucara River that flows into the Lake Titicaca, about $40 \mathrm{~km}$ to the west of the fossiliferous site. The Calapuja Fm. was originally defined by Laubacher $(1977,1978)$ and redescribed by Villas et al. (2015: Figure 2). According to the latter authors, the unit is about 2,200-2,500 m thick, with 10-12 thick-bedded quartzitic packages, each up to $100 \mathrm{~m}$ thick, separated by shaly siltstones and sandstones. The studied fossiliferous sandstone horizon is $60 \mathrm{~m}$ below the base of the third quartzitic unit that crops out above the basal fault that separates the Calapuja Fm. from Silurian strata. The brachiopod species from that horizon are mostly endemic for the region and the genera to which they correspond present a strong Gondwanan taxonomic signature (Villas et al., 2015). Nevertheless, these authors also found two brachiopod species known from the British Burrellian Stage of the Caradoc Series, allowing them to indirectly correlate the fossiliferous horizon with the upper Sandbian global stage (Sa2 of Bergström et al., 2009).

\section{MATERIALS AND METHODS}

Two hundred and fifteen specimens of Palaeosabella prisca (McCoy, 1855) on disarticulated valves belonging to Colaptomena expansa (Sowerby, 1839) and Heterorthis retrorsistria (McCoy, 1851) were re-studied from the collection of Villas et al. (2015).

The studied brachiopod shells are well preserved as both internal and external moulds. Our study resulted in recognition of tubular or cylindro-clavate macroborings described herein, which was observed on dorsal and ventral valves belonging to those brachiopods.

To undertake this study has been adopted the methodology proposed by Alexander (1994) and used by Santos et al. (2014) to represent the position of the ichnotaxon and their spatial distribution in the brachiopod shells. Each brachiopod valve was divided into eighteen areas to partition the distribution of trace fossils following a methodology similar to Alexander's (1994). Borings inside these areas were counted and measured using the measurement tools of ImageJ 1.46r software. 

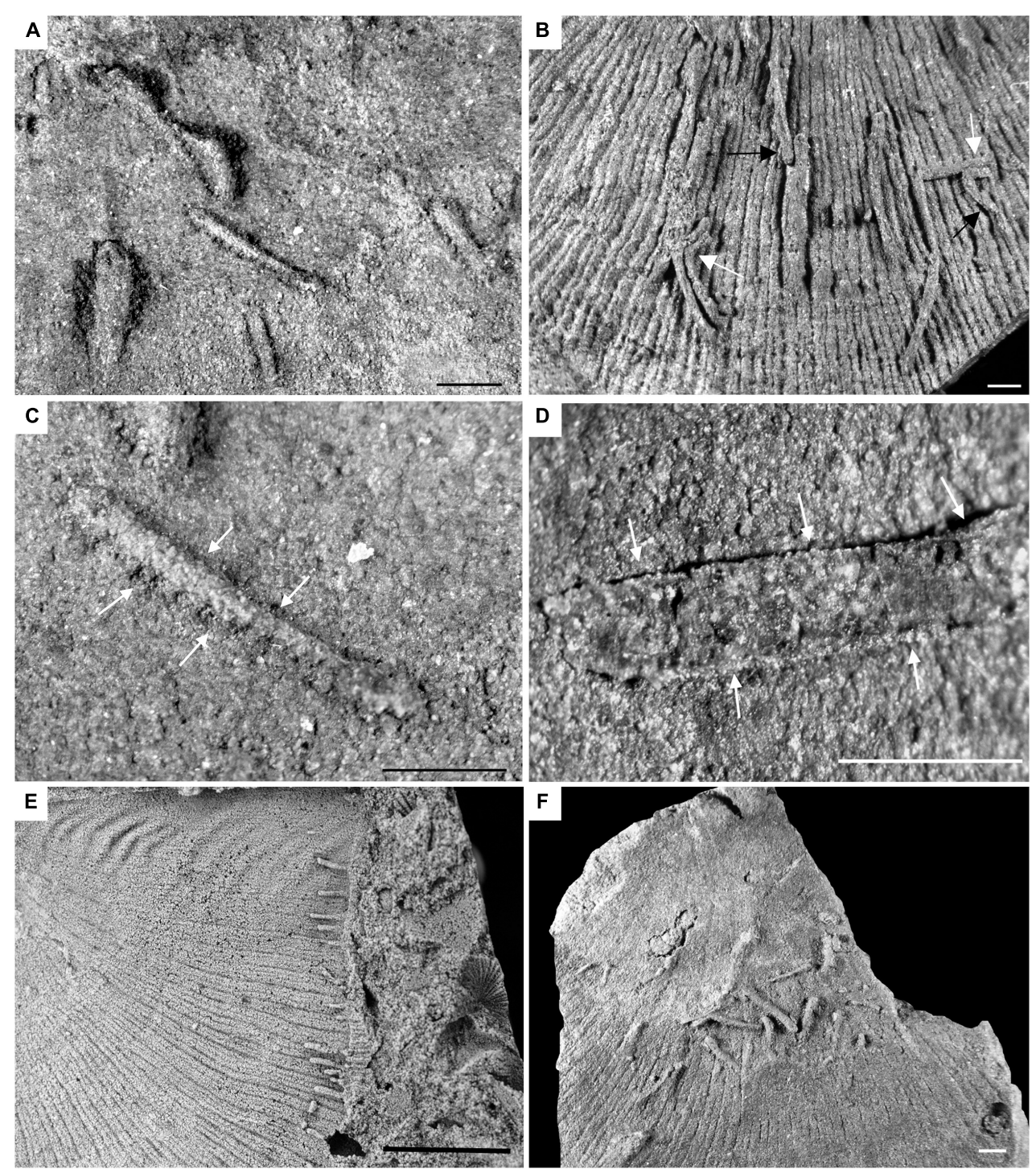

FIGURE 1 | Valves of Colaptomena expansa with Palaeosabella prisca borings. (A-C) External moulds of ventral valves. (A) Showing a rounded and clavate terminus (CPI-1001). (B) Borings closely crowded touching and bending their trajectory (white arrows) or overlapping slightly (black arrow) (CPI-10002).

(C) Specimen showing the filling with a rough transverse segmentation and remains of the lining (white arrows) (CPI-10001). (D) Close-up view of a tube lined with some silt-sized sediment grains (white arrows). Internal mould of ventral valve (CPI-6506). (E) Borings arranged parallel to the radial ornamentation and oriented toward the umbo. External mould of ventral valve (CPI-6504a). (F) Borings randomly arranged (CPI-10003). All scale bars =1 mm.

\section{SYSTEMATIC PALAEOICHNOLOGY}

Repository. All the specimens described and illustrated in the following section are housed in the collections of the Instituto Geológico, Minero y Metalúrgico (Lima, Peru), Código Paleontológico INGEMMET (CPI) and assigned registration numbers CPI-6503, 6504, 6506-6519, 6553, 6571, 6572, 6577, 10001-10013.

Ichnogenus Palaeosabella Clarke, 1921.

Type ichnospecies. Vioa prisca, McCoy, 1855, from Upper Ludlow of Benson Knot, Kendal, Westmoreland.
Synonyms. Vermiforichnus Cameron, 1969a (Type ichnospecies: Vermiforichnus clarkei Cameron, 1969a), Clionoides Fenton and Fenton, 1932 (Type ichnospecies: Clionoides thomasi Fenton and Fenton, 1932).

Remarks. Vermiforichnus Cameron, 1969a and its type ichnospecies V. clarkei Cameron, 1969a were established as replacement ichnotaxa for Palaeosabella Clarke, 1921 and its type ichnospecies P. prisca (McCoy, 1855), respectively. On the other hand, forms attributed to Palaeosabella from the Ordovician of Ohio were described by Taylor and Wilson (2003), Wilson and Palmer (2006), and Wilson (2007). These latter authors suggested that Palaeosabella resembles Trypanites Mägdefrau, 1932, and the two ichnotaxa may be indistinguishable unless a slightly 
clavate terminus is observed. This fact implies that many borings considered to be Trypanites may be Palaeosabella (Bromley, 2004). On the other hand, Vinn et al. (2014) described other borings probably produced by polychaete worms in the Sandbian (Late Ordovician) of Estonia and which previous authors relate to Osprioneides (Beuck et al., 2008). However, the main differences with Palaeosabella lie in the fact that Osprioneides are vertical to subhorizontal borings, with a curved to a sinuous trajectory, with a tapered to rounded terminus and that they do not have linings or septa inside the borings.

Also, Furlong and McRoberts (2014) synonymised Palaeosabella with Clionoides Fenton and Fenton, 1932, although this assumption was erroneous since they did not consider the ICZN rules (International Commission for Zoological Nomenclature [ICZN], 1999: Art. 23).

As stated by Wisshak et al. (2019), a comparison of the holotypes of Vermiforichnus clarkei Cameron (1969a) and $P$. prisca (McCoy, 1855) shows that $P$. prisca is the senior synonym of $V$. clarkei, and as a consequence, Vermiforichnus is synonymous with Palaeosabella.

Palaeosabella prisca (McCoy, 1855).

Figures 1A-F, 2, 3A-F, 4C,D.

McCoy, 1855 Vioa prisca McCoy, p. 260, pl. 1B, Figure 1.
Cameron, 1969b Vermiforichnus clarkei Cameron, p. 692, pl. 1D, Figures 1, 7.

Original description. Straight to curved shell-borings that are circular in cross-section with a usual diameter of about $1 \mathrm{~mm}$.

Diagnosis. Long, unbranched, tubular or cylindro-clavate macroboring that expands distally as an acute cone.

Material. 215 specimens (194 on ventral valves of Colaptomena expansa and 21 specimens on Heterorthis retrorsistria (20 on the dorsal valve and 1 one the ventral one).

Description. Elongated cylindrical tubes, circular in crosssection, commonly straight or more rarely sinusoidal or curved, making a hook or loop. Parallel or slightly inclined to the host surface. The length in Colaptomena valves varies between 0.38 and $8.68 \mathrm{~mm}$, with a mean value of $2.19 \mathrm{~mm}$, while in Heterorthis valves, the length varies between 0.19 and $7.79 \mathrm{~mm}$, with a mean value of $0.88 \mathrm{~mm}$ (Table 1). The tube diameter varies between 0.14 and $1.25 \mathrm{~mm}$, with an average of $0.42 \mathrm{~mm}$ in Colaptomena and $0.08-0.73 \mathrm{~mm}$ in Heterorthis. In general, tubes tend to increase in diameter toward the end closest to the umbo or in its direction (Figures 1A, 4C). The ends are rounded and never have branching. When tubes are closely crowded may touch, in which case they bend and change their trajectory or overlap slightly (Figures 1B, 3F, 4C), but never intersect each other. In general, they are smooth and unsegmented, although a rough transverse segmentation seems to be discernible (Figure 1C). Some specimens also show the presence of a very thin wall, whose thickness varies between 0.04 and $0.11 \mathrm{~mm}$, with an average
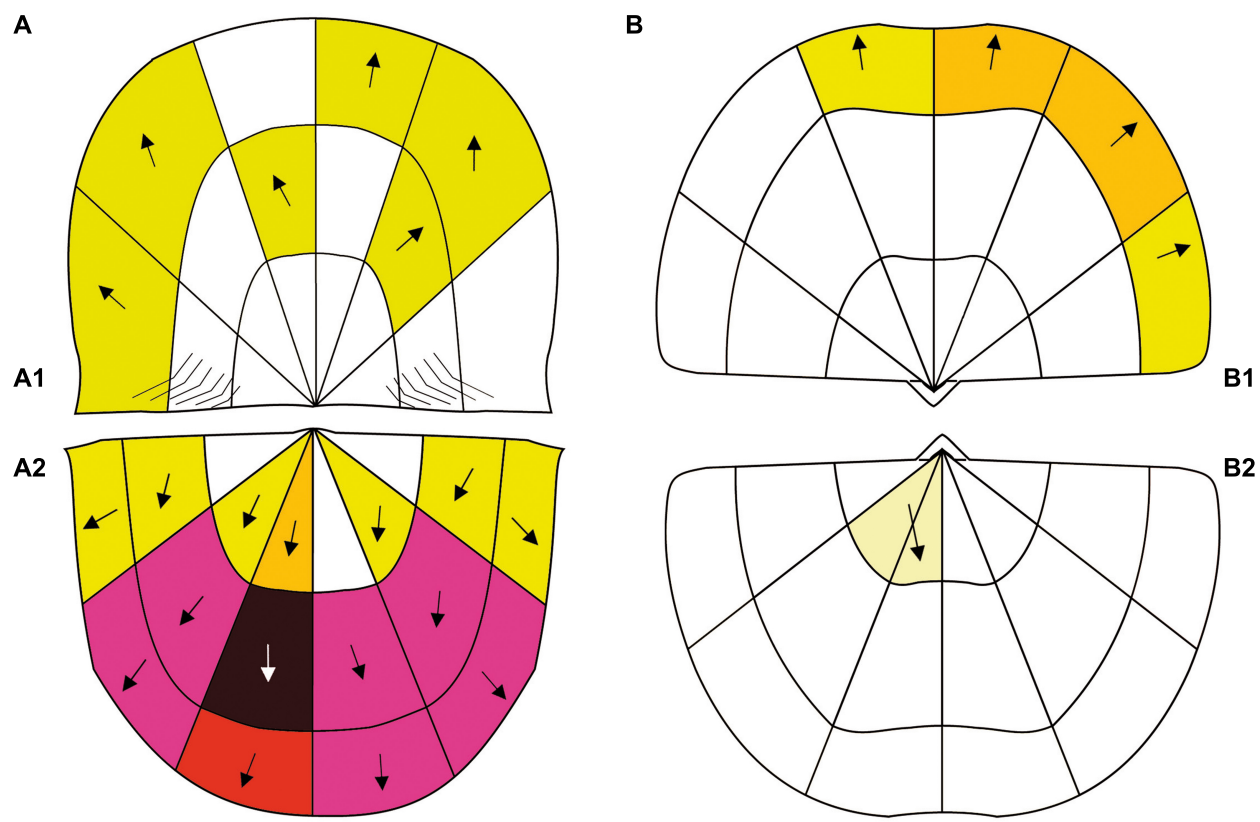

$\mathrm{n}^{\circ}$ specimens

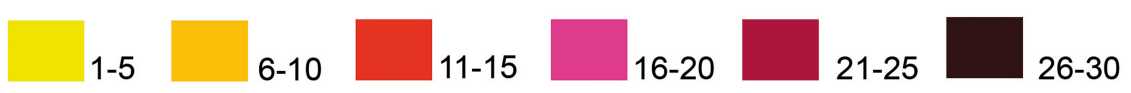

FIGURE 2 | Frequency and spatial distribution of Palaeosabella prisca. (A) On Colaptomena expansa (A1): Dorsal valve, (A2): Ventral valve. (B) On Heterorthis retrorsistria. (B1): Dorsal valve, (B2): Ventral valve. 

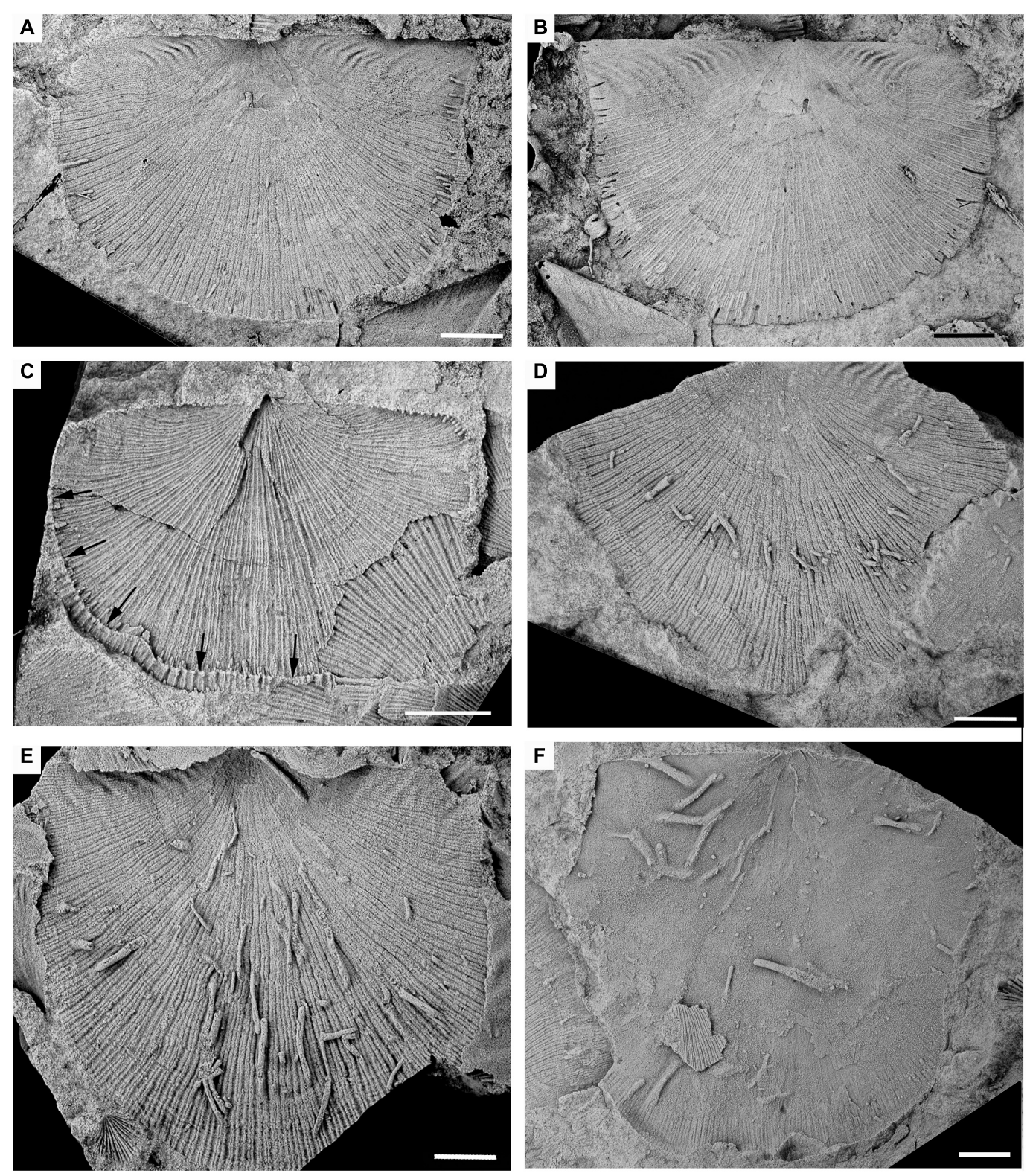

FIGURE 3 | (A-F) Valves of the two brachiopod species recorded in the assemblage hosting Palaeosabella (all scale bars = 5 mm). (A) External mould (A) and latex cast of exterior. (B) Of ventral valve of Colaptomena expansa with borings arranged on valve margins (CPI 6504a). (C) External mould of dorsal valve of Heterorthis retrorsistria with borings arranged on a growth line (CPI 6504b). (D) External mould of ventral valve of Colaptomena expansa with borings randomly arranged throughout the valve surface (CPI-10002). (E) External mould of ventral valve of Colaptomena expansa with borings arranged on a growth line (CPI-10004). (F) Internal mould of ventral valve of Colaptomena expansa with borings disorganised on valve internal surface (CPI-10005).

value of $0.06 \mathrm{~mm}$ (Table 1 ). These walls are lined with some siltsized sediment grains (Figures 1C,D). Specimens are preserved as sediment-filled tubes.

Remarks. Cameron (1969a) attributed these borings to Vermiforafacta, a fossilised spionid polychaete found inside a Vermiforichnus boring (= Palaeosabella). He also observed that the borings were oriented along the commissure of brachiopod shells (Hebertella, Mucrospirifer) and converging toward the umbo, remaining parallel to the shell surface and inside it. This arrangement was also observed by Pickerill (1976) on the Ordovician Heterorthis retrorsistria. Furlong and McRoberts (2014) also observed such an orientation in brachiopods from the Middle Devonian of Central New York, although they included Palaeosabella in Clionoides and attributed its production to ancient boring sponges.

In our case, Palaeosabella appears mostly on the exterior of Colaptomena ventral valves, arranged parallel to the radial ornamentation and oriented toward the umbo (Figures 1E, 3C,D, 4C,D) either on the commissure of the shell or on growth lines (in 9 of the 20 studied valves with 

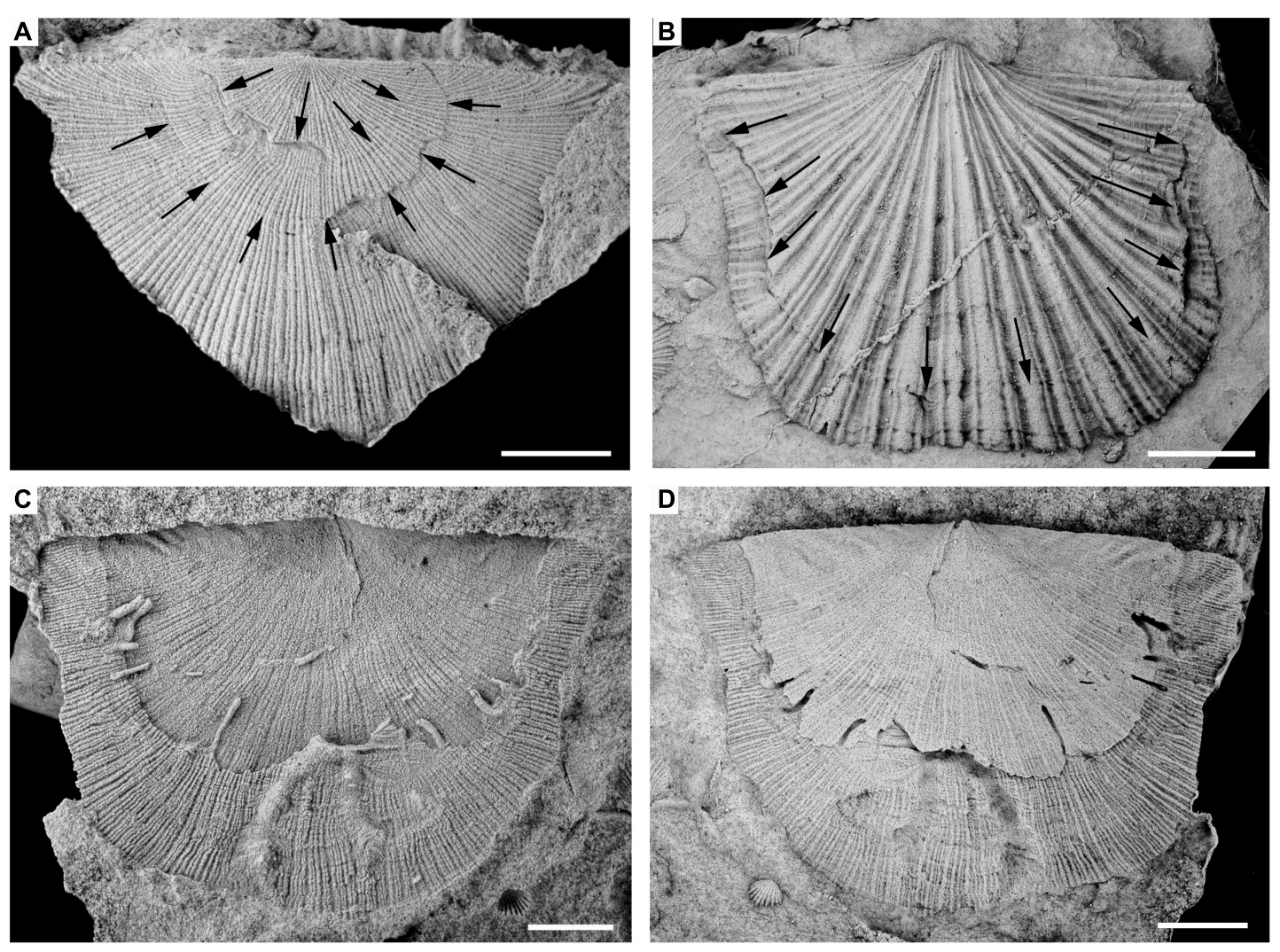

FIGURE 4 | (A-D) Valves of three brachiopod species recorded in the assemblage with repaired broken margins (all scale bars = 5 mm). (A) Latex cast of exterior of dorsal valve of Heterorthis retrorsistria with two successive repaired broken margins (CPI 6577). (B) Latex cast of exterior of ventral valve of Horderleyella chacaltanai with repaired broken margin (CPI 6553). (C,D) External mould and latex cast of exterior of ventral valve of Colaptomena expansa with Palaeosabella borings arranged on repaired broken margin (CPI-6507a).

borings: $45 \%)$. In contrast, in the rest of the bored valves (55\%), they occur randomly (Figures 1F, 3E,F).

The maximum areas of occupation in Colaptomena valves, according to the division proposed by Alexander (1994), are located in the ventral medial and lateral left-right zones, as well as in the ventral anterior lateral left-right zones. To a lesser extent, the borings are located in the ventral lateral right and ventral posterior areas (Figures $\mathbf{2 A 1}, \mathbf{A 2}$ ). In Heterorthis, the maximum occupation zones are commissure of dorsal anterior and dorsal anterior lateral right (Figure 2B1). Less frequently, in the ventral posterior zone (Figure 2B2).

\section{TAPHONOMY AND PALAEOECOLOGY REMARKS}

The ichnofossils studied herein occur exclusively in a single fine sandstone fossiliferous bed of the Calapuja Formation, C3 bed, from where Villas et al. (2015) described five brachiopod species. Of them, we have calculated their relative abundances using the number of the most abundant valve of each species, from a total of 94 valves: Colaptomena expansa (41\%), Heterorthis retrorsistria (24\%), Horderleyella chacaltanai (19\%), Drabovinella minuscula (13\%), and Dinorthis cf. flabellulum (3\%).
Only C. expansa and H. retrorsistria display Palaeosabella borings, most observed on C. expansa valves (51\% of the valves bored) while $H$. retrorsistria presents only $9 \%$ of its studied valves

TABLE 1 | Dimensional parameters of Palaeosabella prisca on Colaptomena expansa and Heterorthis retrorsistria.

Colaptomena expansa (Sowerby, 1839)

\begin{tabular}{lccc}
\hline & Minimum & Maximum & Average (N: 194) \\
\hline Length $(\mathrm{mm})$ & $0.38-2.47$ & $1.66-8.68$ & 2.19 \\
\hline Minimum & Maximum & Average (N:194) \\
\hline Diameter $(\mathrm{mm})$ & $0.14-0.45$ & $0.32-1.25$ & 0.42 \\
\hline Wall width $(\mathrm{mm})$ & Minimum & Maximum & Average (N:14) \\
\hline
\end{tabular}

Heterorthis retrorsistria (McCoy, 1851)

\begin{tabular}{cccc}
\hline & Minimum & Maximum & Average (N: 21) \\
\hline Length $(\mathrm{mm})$ & $0.19-0.32$ & $0.85-7.79$ & 0.88 \\
\hline & Minimum & Maximum & Average (N:21) \\
\hline Diameter $(\mathrm{mm})$ & $0.08-0.59$ & $0.24-0.73$ & 0.19
\end{tabular}


with borings. These results confirm the host specificity of the Palaeosabella producers suggested by Pickerill (1976) for the Ordovician association of central Wales.

All the studied valves are disarticulated, with very low fragmentation and randomly oriented, except for most valves' usual convex side up. They were probably accumulated by the action of storms. Because of their different morphologies, each brachiopod valve behaves differently while transported during the biostratinomic phase (Hallman et al., 1996; Simões and Kowalewski, 2003). Given the different degrees of shape sorting, calculated with their ventral to dorsal valves ratio (vv/dv), they could have suffered different degrees of transport. Some of them would have inhabited a different environment to where they were finally accumulated, possibly a shallow-marine shelf, with shifting fine sand substrate in a high-energy environment. It is the case of C. expansa $(\mathrm{vv} / \mathrm{dv}=17 \%)$ and $H$. retrorsistria $(\mathrm{vv} / \mathrm{dv}=35 \%)$, the two species with borings on their valves and high degrees of shape sorting. On the other hand, D. minuscula $(\mathrm{vv} / \mathrm{dv}=78 \%)$ and $H$. chacaltanai $(\mathrm{vv} / \mathrm{dv}=46 \%)$, with lower degrees of shape sorting, would have suffered a much shorter transport, if any. With only two ventral valves recovered, the low representation of $D$. cf. flabellulum points to more significant transportation or a minority presence in the original community.

The species list of the studied assemblage coincides closely with that of the Dinorthis community described in the Caradoc series of North Wales (Pickerill and Brenchley, 1979), whose characteristic brachiopods are Dinorthis, Heterorthis, Reuschella, Colaptomena (= Macrocoelia), and Rostricellula. Three of them are coincident with the genera in the Calapuja assemblage, namely Dinorthis, Heterorthis, and Colaptomena, and their species: Heterorthis retrorsistria, Colaptomena expansa, and possibly Dinorthis flabellulum. A fourth genus in the community, the harknessellid Reuschella, is played by another genus of the same family, Horderleyella, very close to the former and with intergrading characters (Villas et al., 2015: p. 471). Rostricellula has not been recorded in the Peruvian assemblage, as neither Drabovinella in the Welsh Dinorthis community. These differences can be a consequence of the mixture of taxa of one or several adjacent communities in Calapuja, commented above, and the different palaeobiogeographical situations of both compared palaeoecological associations the Anglo-Welsh Baltic brachiopod province and the High-latitude brachiopod province (Harper et al., 2013).

The coincidence between the Calapuja assemblage and the Dinorthis community is even closer considering its Colaptomena (= Macrocoelia) sub-community, described by Pickerill and Brenchley (1979), dominated by Colaptomena, often forming monospecific assemblages. In this case, the similarity between the Welsh and the Peruvian assemblages is not only in their taxonomic lists but also in their associated lithologies, which are laminated fine-grained sandstones.

The preferred environment of the Colaptomena subcommunity was suggested to be in water depths of 25 $\mathrm{m}$ or less, with low turbidity, slightly more off-shore, lower energy situations, and more stable substrates than the shifting sand typical of the Dinorthis sub-community (Pickerill and Brenchley, 1979). We can interpret that it would be below the fair-weather wave base, known as the upper off-shore or transition zone. Therefore, a similar environment can be regarded for the $\mathrm{C} 3$ assemblage of the Calapuja Formation and the hosting brachiopods of the Palaeosabella producers.

\section{COMMENSALISM VS. PARASITISM}

From the same horizon C3 at Calapuja, rare unordered post-mortem encrustation and multiple oriented syn-vivo encrustation by cornulitids on the exteriors of $C$. expansa shells have been described, with no malformations on those brachiopod shells that could be related to the cornulitids (Vinn and GutiérrezMarco, 2016). In this case, a commensalism relationship between host and encruster is rather clear. The type of biotic relationship between Palaeosabella producers and their host needs a more thorough analysis.

The first question is to discern whether the colonisation occurred during life or post-mortem of the host substrate. It has been suggested that when the borings are oriented, the host was alive (Pickerill, 1976), while when the borings are disorganised or randomly arranged, the opposite is accepted. In C. expansa, more than $80 \%$ of the valves have oriented borings toward the umbo (Figures 1E, 2A1,A2, 3A,B, 4C,D), although only in a $45 \%$ of the cases their openings are on the commissure of the shell or on growth lines. In these cases, there can be a greater certainty that they were produced during the host's life. In H. retrorsistria all the borings in the most colonised valve are also oriented and their openings are arranged on a growth line direction (Figure 3C).

Another issue is to analyse whether the two valves of the brachiopods (mainly C. expansa) were differently colonised and, if so, what caused this. C. expansa has a sub-planar shell, with the ventral valve only slightly convex, becoming more planar in adult stages, and the dorsal valve flat or slightly concave. C. expansa and $H$. retrorsistria have wide, open delthyria without any obturating plates, which would imply that they would have strong pedicles that would allow them to stand upright on them, with the commissure approximately perpendicular to the substrate. Such a position (pedunculate erect) would imply, a priori, a 50/50 probability of colonisation of both valves. Nevertheless, the studied collection displays a strong taphonomic biassed preservation of $C$. expansa valves, being most of them ventral ( $85 \%)$ and a very few dorsal (15\%), with only the posterior part of most dorsal valves preserved. Consequently, although more than $95 \%$ of the colonised valves of the collection are ventral valves, no conclusion can be drawn on the shells' life position when they were colonised.

In some strophomenids, the two valves are strongly dissimilar in the adult stages, with a convex valve, mostly the ventral, and a flat or slightly concave valve, mostly the dorsal, and reduced pedicle openings. In these cases, it is interpreted that they would have been reclining in adult stages, resting on the more convex valve and with the commissure parallel to the substratum (liberosessile morphotype; sensu Sorrentino et al., 2009). In this context, and in the absence of epizoans that could provide additional information on which valve occupies the dorsal position, it seems unlikely that this horizontal arrangement 
of the brachiopod was successful because it would facilitate the sediment inflow into the pallial cavity and difficult the exchange of water. So, it seems more likely that the brachiopod adopted a pedunculate erect position where the boring host organisms (originally the larvae) could settle at or near the margin of the commissure of the valves, occasionally causing an interruption in the growth of the shell.

Since the boring openings are occasionally arranged on the broken valve margins and the related growth lines of some valves (Figures $4 \mathrm{C}, \mathrm{D}$ ), the origin of the breakage merits to be analysed. Repaired broken margins can be observed frequently on valves of C. expansa (Villas et al., 2015: Figures 6E,M), but also occasionally on those of $H$. retrorsistria (Figure 4A) and H. chacaltanai (Figure 4B). The zigzag shape of the breakage seems to correspond with the embayed type of damage described by Alexander (1986) resulting from the attack of a durophagous predator, most probably a nautiloid. A breakage origin related to impacts of shell fragments seems more unlikely, considering the shape of the breakage and the relatively low energy, off-shore environment occupied by those brachiopods.

The repaired broken valves have developed growth lines continuous with the broken margins, reflecting a shell growth interruption during the healing of the wounded mantle. From the infestation of one of those C. expansa valves by the borers, precisely on the wounded margin and on the shell secreted immediately after it (Figures 4C,D), it can be inferred that the colonisers were taking advantage of a moment of weakness of their host, as well as that the larvae preferred settling on the host soft parts instead of on its shell. It can also be assumed that the brachiopod would have some chemical or physical mechanism to avoid the settling of epizoans larvae on its mantle margin during healthy growing periods.

In the Calapuja assemblage, there is also a case of multiple borings on a $H$. retrorsistria valve, with their openings coinciding with a growth line (Figure 3C), as well as on a valve of $C$. expansa with the openings aligned on the final margin of the valve (Figures 3A,B). Pickerill (1976) also described a single specimen of $H$. retrorsistria with multiple borings oriented perpendicular to the valve commissure and, according to the author, terminating in a growth line. Pickerill (1976) interpreted that the brachiopod growth line was the result of some adverse condition that killed the borers, whereas the host was unaffected and continued to grow. In the systematic description above, we interpret that the growth of the Palaeosabella tubes is toward the umbo of the valve, the direction in which they tend to increase in diameter. Thus, those tubes with the opening arranged on a growth line direction will have there the beginning, not the end. It can also be deduced that the adverse condition that generated the shell growth line is directly connected with the simultaneous settling of numerous boring larvae on its valve margins. It does not seem very likely that the harmful effect of the larvae settling on the brachiopod commissure was simply because they interfered with the feeding currents. On the one hand, the borers did not seem to need it since most of the observed borings begin far from the commissure of their host when it was alive or were developed on dead shells. On the other hand, if the borers had taken advantage of the host's current system, it should be expected to find them concentrated closer to the inhalant water regions of the shells, generally the lateral ones, and not uniformly distributed along the commissure, as they occur (see Figure 2).

The observed interaction between the borer settling and the brief growth interruption of their host shell can be more easily understood if the settling larvae go through a short period of feeding on their host soft parts. After that, they would develop the palps that allowed them to feed themselves as suspensivorous animals. That would explain: (1) the detrimental effect on their host growth rate that resulted in the development of growth lines on their shells; (2) the fact that they could only settle on the commissure of weakened animals, recently injured by predators (Figures 4C,D) or close to their death (Figures 3A-C). The ability of healthy brachiopods to avoid the boring larvae to settle on their commissure is also a clue about the harmful effect it had on them. Nevertheless, if the epizoan larvae went through an early parasitic period in which they fed on the host organic tissues, it must be explained how those larvae that settled far from the shell margins, or even on dead shells, survived to that period. The proteinaceous external layer, the periostracum, characteristic of all the brachiopods, although rarely found in the fossilised state (Williams, 1997), can be the answer.

The behaviour of the lecitotrophic larvae and the adult stages of Recent spionid polychaetes, as several Polydora species that generate borings similar to Palaeosabella is well known (Dorsett, 1961; Haigler, 1969; Hansen et al., 2010; Martinelli et al., 2020). Nevertheless, as far as we know, the initial stages of their larvae after they settle on their host shell and before they begin the boring activity and develop food-gathering palps have not been described. Studies on those Recent larval initial settling stages would allow testing the hypothesis above on the interaction between the Ordovician borers and their hosts. If the proposed results hypothesis is correct, the biotic interaction between the borers and the host was initially of the parasitic type. However, to speak of parasitism does not seem possible in subsequent developmental stages of the borers, and the interaction with their host can be interpreted then as commensalism. In this context, maybe it was possible that at the larval stage the borers were parasitic and later on, it lived as commensal. In their adult stages, the producers of Palaeosabella (spionid worms according to Cameron, 1969a,b; Pickerill, 1976) only secondarily caused damage to the host due to their boring activity and not because they feed on the host's shell or body. This activity can weaken the host shell and make it more susceptible to breaking into turbulent waters.

\section{PALAEOGEOGRAPHIC REMARKS}

The close palaeobiogeographical affinities during the Early and Mid-Ordovician of Avalonia (Cocks and Torsvik, 2002) with different regions of the Proto-Andean margin of Gondwana, represented today by Puna-Famatina in Argentina (Benedetto, 1998, 2003), the Eastern Cordillera of Peru (Gutiérrez-Marco and Villas, 2007) and the Peruvian Altiplano (Colmenar and Hodgin, 2021) are well known. In all those regions and epochs, 
the brachiopod assemblages are recognised to belong to the same Celtic Province of Williams (1973).

By the Sandbian times, the age when the symbiotic association we describe from Peru and Wales occurred, Avalonia had drifted away from Gondwana, and the Rheic Ocean separated both continents more than $3,000 \mathrm{~km}$ away, according to most palaeogeographical reconstructions (Pohl et al., 2015; Torsvik and Cocks, 2017; Figure 5). Avalonia had quickly increased its faunal affinity with Baltica, becoming faunistically indistinguishable by the latest Ordovician (Cocks and Fortey, 1982). By the Sandbian, Harper et al. (2013) identify an AngloWelsh Baltic brachiopod province, with a great taxonomic distance from a High-Latitude brachiopod province, which included the South-American localities. Nevertheless, despite the critical taxonomic differences between both provinces, with only a few common brachiopod genera, and of the enormous geographic distance between them, three brachiopod species have demonstrated to be able to come across the Rheic Ocean, colonising its opposite margins: Colaptomena expansa, Heterorthis retrorsistria, and Dinorthis flabellulum. Although these latter species are only provisionally referred to in the Peruvian assemblage, they were distinctly identified in the Upper Ordovician of the neighbour Bolivia by Havlíček and Branisa (1980). Villas et al. (2015) remarked the need for the presence of intermediate islands in the Rheic Ocean to make possible the transit of the three species between both continents, considering the low dispersal potential of the Rhynchonelliformean brachiopods. The short-lived, not planktotrophic larvae of their Recent representatives go through a very brief free-swimming phase, settling on the substrate in hours to a few days (Richardson, 1997). Assuming the same behaviour in the ancient Rhynchonelliformean and the presence of intermediate islands, it must also be considered the existence of an ocean current fast enough to transport the planktic brachiopod larvae from one island to another before their metamorphosis and settlement. That current must have been the Southern Westerlies, flowing west to east immediately north of the Rheic convergence (Figure 5). Pohl et al. (2015) estimated that the Southern Westerlies would have connected the ProtoAndean margin of Gondwana with Avalonia during the Mid to Late Ordovician transition under very different hypothetical atmospheric $\mathrm{CO}_{2}$ levels and ocean temperatures.

Because the great morphological coincidences in the Ordovician Palaeosabella borings from Peru and Wales, and the remarkable coincidence in the species specificity of their producers with their brachiopod hosts, it would be assumed that the ichnofossils were produced by the same or related spionid annelid species. These annelids should have also gone through a planktic larval stage, as long lasting as that of their hosts, at least, in order to be able to follow them in their route through

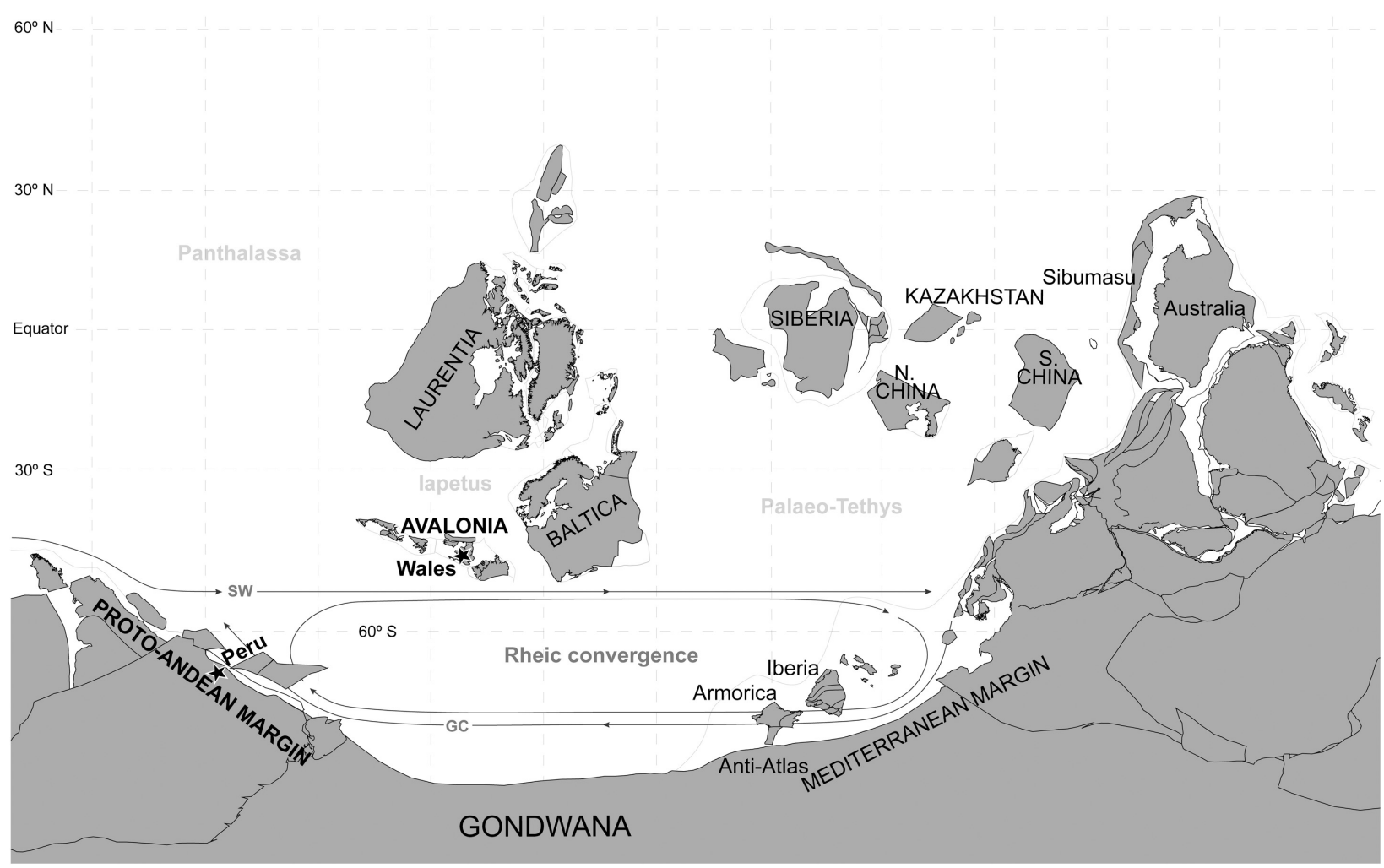

FIGURE 5 | Palaeogeographical reconstruction for the Sandbian (Upper Ordovician), with the location of the compared localities from Peru and Wales and the oceanic currents discussed in the palaeogeographic remarks. SW, Southern Westerlies; GC, Gondwanan Current. Based on Harper et al. (2013), Pohl et al. (2015), and Villas et al. (2015) and Bugplates, and using a Molle wide projection. 
the Rheic Ocean. Something very likely, considering the known larval development of Recent Spinioniform Polychaeta. Some of them with strong swimmer planktotrophic larvae remain planktic up to 45 days before settlement and metamorphosis, while others with weak swimmer lecitotrophic larvae settle within hours or at most a few days (Blake and Neubert, 1999). The same Southern Westerlies current would have transported the planktic larvae of the Palaeosabella producers and those of the brachiopods on which they were dependent. Both hosts and parasites covered the same route during the Sandbian in a successful long-distance biotic relationship.

\section{CONCLUSION}

An Upper Ordovician Peruvian brachiopod fauna from the Proto-Andean margin of Gondwana was re-exanimated and compared with material from Wales (Avalonia) to check the type of biotic relationship between these brachiopods and their borers, most probably polychaete spionids. The traces attributed to these spionids have been identified as Palaeosabella prisca consisting of a long, unbranched, tubular or cylindroclavate macroboring that expand distally as an acute cone. However, these borings are only present in Colaptomena expansa and Heterorthis retrorsistria, which display a resedimented taphonomic condition, characterised by high disarticulation, low fragmentation, and random orientation.

Annelid larvae settled at or near the margin of the commissure of the valves would suggest colonisation in the host's life. In the first stage, the settled larvae would feed on the soft parts of their host so that the biotic interaction could be regarded as parasitic. However, larvae that settle far from the shell margins, or even on dead shells, would behave differently and may have survived on the hosts' periostracum, the proteinaceous outer layer. It can be concluded that the Palaeosabella studied were produced by the same species of spionid annelid since their morphological characteristics are identical and the specificity of their producers to their hosts.

\section{REFERENCES}

Alexander, R. R. (1986). Resistance to and repair of shell breakage induced by durophages in Late Ordovician brachiopods. J. Paleontol. 60, 273-285. doi: $10.1017 / \mathrm{s} 0022336000021806$

Alexander, R. R. (1994). Distribution of pedicle boring traces and the life habit of Late Paleozoic leiorhynchid brachiopods from dysoxic habitats. Lethaia 27, 227-234. doi: 10.1111/j.1502-3931.1994.tb01414.x

Benedetto, J. L. (1998). "Early Paleozoic brachiopods and associated shelly faunas from western Gondwana: their bearing on the geodynamic history of the preAndean margin," in The Proto-Andean Margin of Gondwana, eds R. J. Pankhurst and C. W. Rapela (London: Geological Society of London), 57-83. doi: 10.1144/ GSL.SP.1998.142.01.04

Benedetto, J. L. (2003). “Paleobiogeography," in Ordovician Fossils of Argentina, ed. J. L. Benedetto (Argentina: Universidad Nacional de Córdoba), 91-109.

Bergström, S. M., Chen, X., Gutiérrez-Marco, J. C., and Dronov, A. (2009). The new chronostratigraphic classification of the Ordovician System and its relations to major regional series and stages and to $\delta 13 \mathrm{C}$ chemostratigraphy. Lethaia 42 , 97-107. doi: 10.1111/j.1502-3931.2008.00136.x
The transport of annelid and brachiopod larvae had to be via the Southern Westerlies current connecting the Proto-Andean Gondwana margin with Avalonia.

\section{DATA AVAILABILITY STATEMENT}

The original contributions presented in the study are included in the article/supplementary material, further inquiries can be directed to the corresponding author/s.

\section{AUTHOR CONTRIBUTIONS}

EV gathered and prepared all brachiopod data and made some figures. EM and AS gathered and prepared ichnological data, performed calculations, and made some figures. All authors contributed to the discussion of results and sharing the writing of the manuscript.

\section{FUNDING}

EV received funding from the Government of Aragón to the Research Group E33_20R. EM and AS received funding from the Andalusian Government to the Research Group RNM276 and from the Spanish Ministry of Science and Innovation project PID2019-104625RB-100. JG-M received funding from Spanish Ministry of Science and Innovation project CGL2017-87631-P and of the IUGS-UNESCO Project IGCP 735, "Rocks and the Rise of Ordovician Life."

\section{ACKNOWLEDGMENTS}

We thank Luz Tejada (INGEMMET) for access to specimens in her care.

Beuck, L., Wisshak, M., Munnecke, A., and Freiwald, A. (2008). A giant boring in a silurian stromatoporoid analysed by computer tomography. Acta Palaeontol. Pol. 53, 149-160. doi: 10.4202/app.2008. 0111

Blake, J. A., and Neubert, P. L. (1999). Reproduction and larval development of the spioniform Polychaeta with application to systematics and phylogeny. Hydrobiologia 402, 57-106. doi: 10.1023/A:100378432 4125

Bromley, R. G. (2004). “A stratigraphy of marine bioerosion," in The Application of Ichnology to Palaeoenvironmental and Stratigraphic Analysis, ed. D. Mcilroy (London: Geological Society of London), 455-481. doi: 10.1144/gsl.sp.2004. 228.01.20

Cameron, B. (1969a). New name for Palaeosabella prisca (McCoy), a Devonian worm-boring, and its preserved probable borer. J. Paleontol. 43, 189-192.

Cameron, B. (1969b). Paleozoic shell-boring annelids and their trace fossils. Am. Zool. 9, 689-703. doi: 10.1093/icb/9.3.689

Clarke, J. M. (1921). Organic Dependence and Disease, Their Origin and Significance. New York, NY: New York State Museum Bulletin, 1-113. doi: 10.5962/bhl.title.19803 
Cocks, L. R. M., and Fortey, R. (1982). Faunal evidence for oceanic separations in the Palaeozoic of Britain. J. Geol. Soc. 139, 465-478. doi: 10.1144/gsjgs.139.4. 0465

Cocks, L. R. M., and Torsvik, T. H. (2002). Earth geography from 500 to 400 million years ago: a faunal and palaeomagnetic review. J. Geol. Soc. 159, 631-644. doi: 10.1144/0016-764901-118

Colmenar, J., and Hodgin, E. B. (2021). First evidence of Lower-? Middle Ordovician (Floian-?Dapingian) brachiopods from the Peruvian Altiplano and their paleogeographical significance. J. Paleontol. 95, 56-74. doi: 10.1017/jpa. 2020.72

Díaz-Díaz, O., and Liñero-Arana, I. (2009). Porcentaje del grado de infestación de Polydora cf. websteri Hartman 1943 (Polychaeta: spionidae) por clase de talla de Crassostrea rhizhophorae (Guilding 1828) de la laguna La Restinga (Isla Margarita, Venezuela). Rev. Cient. 19, 113-118.

Diez, M. E., Radashevsky, V. I., Orensanz, J. M., and Cremonte, F. (2011). Spionid polychaetes (Annelida: spionidae) boring into shells of molluscs of comercial interest in northern Patagonia. Argentina. Ital. J. Zool. 78, 497-504. doi: 10. 1080/11250003.2011.572565

Dorsett, D. A. (1961). The behaviour of Polydora ciliata (Johnst.). Tube-Building and Burrowing. J. Mar. Biol. Assoc. U. K. 41, 577-590. doi: 10.1017/ S0025315400016167

Ebbestad, J. O. R., and Gutiérrez-Marco, J. C. (2000). Phragmolites (Gastropoda) from the Late Ordovician of the Peruvian Altiplano. J. Paleontol. 94, 255-265. doi: $10.1017 /$ jpa.2019.79

Fenton, C. L., and Fenton, M. A. (1932). Boring sponges in the Devonian of Iowa. Am. Midl. Nat. 13, 42-54. doi: 10.2307/2419951

Furlong, C. M., and McRoberts, C. A. (2014). Commensal borings from the Middle Devonian of central New York, ecologic and taxonomic review of Clionoides, Clionolithes, and Canaliparva n. ichnogen. J. Paleontol. 88, 130-144. doi: 10. $1666 / 12-141$

Gutiérrez-Marco, J. C., and Villas, E. (2007). Brachiopods from the uppermost Lower Ordovician of Peru and their palaeogeographical significance. Acta Palaeontol. Pol. 52, 547-562.

Haigler, S. A. (1969). Boring mechanism of Polydora websteri inhabiting Crassostrea virginica. Am. Zool. 9, 821-828. doi: 10.1093/icb/9.3.821

Hallman, D. P., Jonathan, D. M., and Flessa, K. W. (1996). Experimental taphonomy: the effect of shell size and shape on transport within the intertidal zone. Sixth North American Paleontological Convention. Paleontol. Soc. Spec. Publication 8:157. doi: 10.1017/S2475262200001593

Hansen, B. W., Jakobsen, H. H., Andersen, A., Almeda, R., Pedersen, T. M., Christensen, A. M., et al. (2010). Swimming behavior and prey retention of the polychaete larvae Polydora ciliata (Johnston). J. Exp. Biol. 213, 3237-3246. doi: $10.1242 /$ jeb. 038810

Harper, D. A. T., Rasmussen, C. M. O., Liljeroth, M., Blodgett, R. B., Candela, Y., Jin, J., et al. (2013). "Biodiversity, biogeography and phylogeography of Ordovician rhynchonelliform brachiopods," in Early Palaeozoic Biogeography and Palaeogeography, eds D. A. T. Harper and T. Servais (London: Geological Society of London), 127-144. doi: 10.1144/M38.11

Havlíček, V., and Branisa, L. (1980). Ordovician brachiopods of Bolivia (Succession of assemblages, climate control, affinity to Anglo-French and Bohemian provinces). Praha: Academia nakladatelstvií Československé akademie věd, $1-54$.

Huntley, J. W., and Kowalewski, M. (2007). Strong coupling of predation intensity and diversity in the Phanerozoic fossil record. Proc. Natl. Acad. Sci. U. S. A. 38, 15006-15010. doi: 10.1073/pnas.0704960104

International Commission for Zoological Nomenclature [ICZN] (1999). International Code of Zoological Nomenclature, Adopted by the International Union of Biological Sciences, 4th Edn. London: International Trust for Zoological Nomenclature.

Laubacher, G. (1977). Géologie des Andes Peruviennes. Géologie de l'Altiplano et de la Cordillère Orientale au nord et nord-ouest du lac Titicaca (Pérou). Ph.D. thesis. Académie de Montpellier: Université des Sciences et Techniques du Languedoc, 117

Laubacher, G. (1978). Estudio Geológico Preliminar de la Cordillera Oriental. III. Estudio Geológico del Bloque C, Dpto. Puno. Lima: Office de la Recherche Scientifique et Technique Outre Mer (ORSTOM) and Servicio de Geología y Minería (SGM), 89.
Mägdefrau, K. (1932). Über einige Bohrgänge aus dem unteren Muschelkalk von Jena. Paläontol. Z. 14, 150-160. doi: 10.1007/BF03041628

Martinelli, J. C., Lopes, H. M., Hauser, L., Jimenez-Hidalgo, I., King, T. L., PadillaGamiño, J. L., et al. (2020). Confirmation of the shell-boring oyster parasite Polydora websteri (Polychaeta: spionidae) in Washington State, USA. Sci. Rep. 10:3961. doi: 10.1038/s41598-020-60805-w

McCoy, F. (1851). On some new Cambro-Silurian fossils. Ann. Mag. Nat. Hist. 8, 387-409. doi: 10.1080/03745486109494991

McCoy, F. (1855). British Paleozoic Fossils. UK: London and Cambridge, 659.

Pickerill, R. K. (1976). Vermiforichnus borings from the Ordovician of central Wales. Geol. Mag. 113, 159-164. doi: 10.1017/S001675680003 6451

Pickerill, R. K., and Brenchley, P. J. (1979). Caradoc marine benthic communities on the south Berwyn Hills, North Wales. Palaeontology 22, 229-264.

Pohl, A., Nardin, E., Vanderbroucke, T. R. A., and Donnadieu, Y. (2015). High dependence of Ordovician ocean surface circulation on atmospheric CO2 levels. Palaeogeogr. Palaeoclimatol. Palaeoecol. 458, 39-51. doi: 10.1016/j.palaeo.2015. 09.036

Radashevsky, V. I., and Olivares, C. (2005). Polydora uncinata (Polychaeta: spionidae) in Chile: an accidental transportation across the Pacific. Biol. Invasions 7, 489-496. doi: 10.1007/s10530-004-5686-0

Richardson, J. R. (1997). "Ecology of articulated brachiopods," in Treatise on invertebrate paleontology. Part H. Brachiopoda 1 (revised), ed. R. L. Kaesler (Lawrence, KS: Geological Society of America, Boulder, CO, and University of Kansas Press), 539.

Santos, A., Mayoral, E., Villas, E., Herrera, Z., and Ortega, G. (2014). First record of Podichnus in orthide brachiopods from the Lower Ordovician (Tremadocian) of NW Argentina and its relation to the early use of an ethological strategy. Palaeogeogr. Palaeoclimatol. Palaeoecol. 399, 67-77. doi: 10.1016/j.palaeo.2014. 02.003

Servais, T., Owen, A. W., Harper, D. A. T., Kröger, B., and Munnecke, A. (2010). The Great Ordovician Biodiversification Event (GOBE): the palaeoecological dimension. Palaeogeogr. Palaeoclimatol. Palaeoecol. 294, 99-119. doi: 10.1016/ j.palaeo.2010.05.031

Simões, M. G., and Kowalewski, M. (2003). "Modern accumulations of brachiopod shells in unconsolidated surficial beach deposits, northern coast of São Paulo State, Brazil: taphonomic implications for the genesis of skeletal concentration," in Proceedings of the $3^{\text {rd }}$ Latin American Congress of Sedimentology (Belém: MCT/Museu Paraense Emílio Goeldi and Universidade Federal de Pará), 220-223.

Skeel, M. E. (2009). Shell-boring worms (Spionidae: polychaeta) infecting cultivated bivalve molluscs in Australia. J. World Aquac. Soc. 10, 529-533. doi: 10.1111/j. 1749-7345.1979.tb00048.x

Sorrentino, L., Benedetto, J. L., and Carrera, M. G. (2009). Diversidad taxonómica y distribución de los morfotipos de braquiópodos en la Zona de Ahtiella argentina (Ordovícico Medio), Formación San Juan, Precordillera Argentina. Ameghiniana 46, 481-493.

Sowerby, J. D. C. (1839). "Fossil shells of the lower Ludlow age," in The Silurian System, Founded on Geological Researches in the Counties of Salop, Hereford, Radnor, Montgomery, Caermarthen, Brecon, Pembroke, Monmouth, Gloucester, Worcester, and Stafford; With Descriptions of the Coalfields and Overlying Formations, ed. R. I. Murchison (London: John Murray), 579-712.

Tapanila, L., and Copper, P. (2002). Endolithic trace fossils in Ordovician-Silurian corals and stromatoporoids, Anticosti Island, Eastern Canada. Acta Geol. Hisp. $37,15-20$.

Taylor, P. D., and Wilson, M. A. (2003). Palaeoecology and evolution of marine hard substrate communities. Earth Sci. Rev. 62, 1-103. doi: 10.1016/S00128252(02)00131-9

Torsvik, T. H., and Cocks, L. R. M. (2017). Earth History and Palaeogeography. Cambridge: Cambridge University Press, 317. doi: 10.1017/9781316225523

Villas, E., Colmenar, J., and Gutiérrez-Marco, J. C. (2015). Late Ordovician brachiopods from Peru and their Paleobiogeographical relationships. Palaeontology 58, 455-487. doi: 10.1111/pala.12152

Vinn, O., and Gutiérrez-Marco, J. C. (2016). New Late Ordovician cornulitids from Peru. Bull. Geosci. 91, 89-95. doi: 10.3140/bull.geosci.1595

Vinn, O., Wilson, M. A., and Mõtus, M. A. (2014). The Earliest Giant Osprioneides Borings from the Sandbian (Late Ordovician) of Estonia. PLoS One 9:e99455. doi: 10.1371/journal.pone.0099455 
Williams, A. (1973). Distribution of brachiopod assemblages in relation to Ordovician palaeogeography. Spec. Pap. Palaeontol. 12 241-269.

Williams, A. (1997). "Shell structure," in Treatise on Invertebrate Paleontology, Part H, Brachiopoda Revised, eds A. Williams, C. H. C. Brunton, and J. Carlson (Kansas: The Geological Society of America and the University of Kansas. Boulder, Colorado and Lawrence), 267-320.

Wilson, M. A. (2007). "Macroborings and the evolution of marine bioerosion," in Trace Fossils: Concepts, Problems, Prospects, ed. W. Miller (Amsterdam: Elsevier), 356-367. doi: 10.1016/B978-044452949-7/50146-7

Wilson, M. A., and Palmer, T. J. (2001). The Ordovician Bioerosion Revolution. Geol. Soc. Am. 33:248.

Wilson, M. A., and Palmer, T. J. (2006). Patterns and Processes in the Ordovician Bioerosion Revolution. Ichnos 13, 109-112. doi: 10.1080/104209406008 50505

Wisshak, M., Knaust, D., and Bertling, M. (2019). Bioerosion ichnotaxa: review and annotated list. Facies 65, 1-39. doi: 10.1007/s10347-019-0561-8
Conflict of Interest: The authors declare that the research was conducted in the absence of any commercial or financial relationships that could be construed as a potential conflict of interest.

Publisher's Note: All claims expressed in this article are solely those of the authors and do not necessarily represent those of their affiliated organizations, or those of the publisher, the editors and the reviewers. Any product that may be evaluated in this article, or claim that may be made by its manufacturer, is not guaranteed or endorsed by the publisher.

Copyright (c) 2021 Villas, Mayoral, Santos, Colmenar and Gutiérrez-Marco. This is an open-access article distributed under the terms of the Creative Commons Attribution License (CC BY). The use, distribution or reproduction in other forums is permitted, provided the original author(s) and the copyright owner(s) are credited and that the original publication in this journal is cited, in accordance with accepted academic practice. No use, distribution or reproduction is permitted which does not comply with these terms. 